\title{
Investigation of the Usage of Whitening Agents as an Alternative to Zircon in Opaque Frit Compositions
}

\author{
B. YILDIZ ${ }^{a, *}$, Z. B. OzTURK ${ }^{b}$ \\ ${ }^{a}$ Yurtbay Seramik, Oklubalı Köyü İnönü/Eskişehir, Türkiye \\ ${ }^{b}$ Nevşehir Hacı Bektaş Veli University, Faculty of Engineering and Architecture, Department of Metallurgical and \\ Materials Engineering, Nevşehir, Türkiye
}

\begin{abstract}
Zircon is the main opacifier in the ceramic sector, however its high cost limits its wide use and has led to the search of alternative materials. Nowadays, industrial whitening agents with different chemical formulas have started to be used in engobe, glaze and body compositions instead of zircon, to reduce raw material cost. Therefore, the purpose of this study is to investigate the possibility of usage of different industrial whitening agents as an alternative to zircon in opaque frit compositions. It was shown that, all of the studied whitening agents decreased the sintering and softening temperatures of the wall tile glazes. Although, alumina based whitening agents caused a glaze with transparent and boiling appearance, alumina with zircon and silica based whitening agents caused glazes with semi-opaque and glossy appearance. Even though none of the studied glazes has reached the standard whiteness indice, results suggest that alumina with zircon and silica based whitening agents could be a good candidate for zircon substitution in opaque frit compositions.
\end{abstract}

DOI: $10.12693 /$ APhysPolA.127.1180

PACS: 81.05.Je

\section{Introduction}

Opacifiers provide opacity to the glaze by scattering and reflecting the incident light. The factors that control the opacity in glazes include the difference in refractive index between the glass and opacifier, the number, size, shape and distribution of the opacifier particles, the incident light wavelength and the glaze thickness [1]. There is no doubt that zircon is the main opacifier agent used in the ceramic tile industry. Zirconia-containing glazes are used not only because of their high whiteness and opacity, but also because of the good mechanical and chemical properties imparted to the glazes [2]. Among commercial frits, those containing zircon and zirconia are of great interest. This type of frits, which are glossy, opaque, viscous and with low fusibility, are composed by $\mathrm{SiO}_{2}(50-$ 60 wt.\%), $\mathrm{ZrO}_{2}$ (8-14 wt.\%) and fluxing elements such as $\mathrm{Na}_{2} \mathrm{O}, \mathrm{K}_{2} \mathrm{O}, \mathrm{PbO}$ and $\mathrm{B}_{2} \mathrm{O}_{3}$ (20-25 wt.\%), as major components and stabilizing elements such as $\mathrm{ZnO}, \mathrm{Al}_{2} \mathrm{O}_{3}$, $\mathrm{CaO}, \mathrm{BaO}, \mathrm{MgO}$ as minor components [3, 4]. However, the high cost of zircon limits its wide use in glaze compositions and has led to a search of alternative materials. It is known that in the ceramic tile sector, whitening agents with different chemical compositions are started to be used in body, engobe and glaze formulations instead of zircon to reduce raw material cost. The purpose of this study is to investigate the possibility of usage of industrial whitening agents as an alternative to zircon in opaque frit compositions. To achieve this aim, several whitening agents were supplied from different indus-

*corresponding author; e-mail: betulkarademir@gmail.com trial companies. Whitening agents with different chemical composition were introduced into opaque frit instead of zircon. The effect of compositional changes on thermal behavior, phase evolution and optical properties of glazes were investigated in this study.

\section{Experimental procedure}

The particle size distributions of the whitening agents were measured using a Malvern Mastersizer 2000 G Particle Size Device. XRD analyses of the whitening agents were conducted by a Rigaku Rint 2000 series diffractometer with $\mathrm{Cu} \mathrm{K}_{\alpha}$ radiation working at $40 \mathrm{kV}$ and $30 \mathrm{~mA}$, with the scanning velocity of $2 \circ / \mathrm{min}$. The chemical composition of whitening agents is given in Table $\mathrm{I}$.

Chemical analyses of the whitening

TABLE I agents (wt.\%).

\begin{tabular}{c|c|c|c|c|c|c|c|c}
\hline $\begin{array}{c}\text { Whitening } \\
\text { agent }\end{array}$ & $\mathrm{Na}_{2} \mathrm{O}$ & $\mathrm{CaO}$ & $\mathrm{MgO}^{-\mathrm{Al}_{2} \mathrm{O}_{3}}$ & $\mathrm{SiO}_{2}$ & $\mathrm{ZrO}_{2}$ & $\mathrm{ZnO}^{\mathrm{TiO}_{2}}$ \\
\hline $\mathrm{A}$ & $<1$ & - & - & $>98$ & $<1$ & - & & - \\
$\mathrm{B}$ & $<1$ & $<1$ & - & $>90$ & $<1$ & - & & 7 \\
$\mathrm{C}$ & $<2$ & $<1$ & $<1$ & $>75$ & - & $>8.5$ & - & $<1$ \\
$\mathrm{D}$ & $<2$ & $<1$ & $<1$ & $>15$ & $<38$ & 41 & $<5$ & - \\
$\mathrm{E}$ & $<2$ & $<1$ & $<1$ & $>53$ & $<16$ & $>24$ & & $<1$
\end{tabular}

For frit preparation, whitening agents were introduced into the standard opaque frit recipe (Table II) instead of zircon. Frit recipes were called by the code of whitening agent, they contained; e.g. Frit recipe which containd whitening agent with code A was called Frit (A). The frit recipes were weighed and they were thoroughly mixed. The mixtures were melted in alumina crucibles in a laboratory-type electrically heated furnace (Protherm PLF $160 / 7$ ) at $1450{ }^{\circ} \mathrm{C}$ for $1 \mathrm{~h}$. The melts were then 
quenched by pouring into cold water to obtain frits. For wall tile glaze preparation, 92 wt.\% frit, 8 wt.\% kaolin and 40 wt. $\%$ water and suitable amounts of carboxy methyl cellulose (CMC), sodium tripolyphosphate (STPP) were used. The glaze was milled in a fast laboratory mill until reaching a reject between 1.0 and $1.5 \%$, in an $\neq 325$ sieve (aperture of $45 \mu \mathrm{m}$ ). Glazes were applied on the wall tiles by ragle with $0.55 \mathrm{~mm}$ thickness and fired in a fast firing wall tile industrial roller kiln at $1125^{\circ} \mathrm{C}$ in a 33 min cycle. Glaze recipes were called by the code of frit, they contained; e.g. frit recipe which contain A-coded frit was called Glaze (A).

Standard frit recipe.

TABLE II

\begin{tabular}{l|c}
\hline \hline Raw Material & wt.\% \\
\hline Silica sand & 39 \\
Potassium feldspar and potass. carbonate & 12 \\
Dolamite and calcite & 23 \\
Alumina & 2 \\
Boric oxide & 6 \\
Zinc oxide & 9 \\
Zircon & 9
\end{tabular}

XRD analyses of the the glazes were conducted by a Rigaku Rint 2000 series diffractometer with $\mathrm{Cu} \mathrm{K}_{\alpha}$ radiation working at $40 \mathrm{kV}$ and $30 \mathrm{~mA}$, with the scanning velocity of $2 \% / \mathrm{min}$. The sintering behaviour of the frits was characterized by hot stage microscopy. The milled frits, with particles smaller than $63 \mu \mathrm{m}$, were pressed in a mould $\left(3 \times 3 \times 3 \mathrm{~mm}^{3}\right)$ and heated from room temperature to $400^{\circ} \mathrm{C}$, at a heating rate of $50^{\circ} \mathrm{C} / \mathrm{min}$ and from $400{ }^{\circ} \mathrm{C}$ to $1450^{\circ} \mathrm{C}$ at a heating rate $10^{\circ} \mathrm{C}$. The colouring parameters $L^{*}, a^{*}$ and $b^{*}$ of the fired samples were measured by means of a Minolta CR-300 series chromometer. Gloss was measured with a gloss meter (Minolta Gloss268) with a $60^{\circ}$ light incident angle on the glaze surface.

\section{Results and discussion}

Figure 1 shows the phase analysis of the whitening agents used in the study. Phase analyses verify the chemical formulas of the agents. All of the whitening agents showed the corundum phase because of their aluminium oxide content. Agent $\mathrm{C}, \mathrm{D}$ and $\mathrm{E}$ shows zircon based phase (zircon and/or baddeleyite). Diffently from the other agents, agent $\mathrm{B}$ showed anatase phase because of its titanium oxide content and agent D showed quartz phase because of its high silicon dioxide content. Table III shows the particle size analyses of the whitening agents. All of the agents' particle size varied between $\approx 1$ to $5 \mu \mathrm{m}$ for $<d(0.5) \mu \mathrm{m}$ and $2-20 \mu \mathrm{m}$, for $<d(0.9) \mu \mathrm{m}$.

The critical temperatures measured by hot stage microscope are shown in Table IV. The sintering temperature of the studied frits changed in a range of $\approx 810$ $950{ }^{\circ} \mathrm{C}$; softening temperature varied in $\approx 920-1050{ }^{\circ} \mathrm{C}$; sphere temperature changed in $\approx 1000-1120^{\circ} \mathrm{C}$; half sphere temperature changed in $\approx 1100-1150{ }^{\circ} \mathrm{C}$ and melting temperature changes in $\approx 1140-1190^{\circ} \mathrm{C}$ ranges.

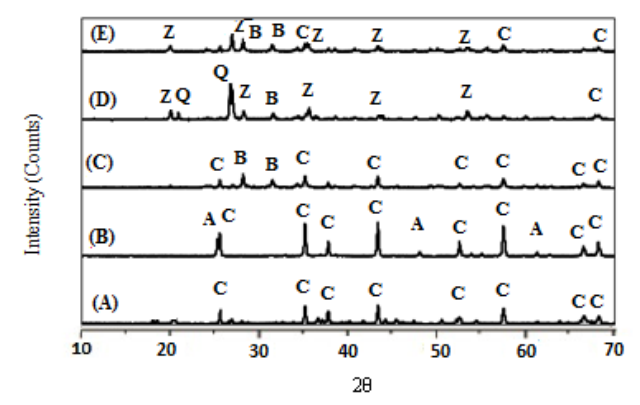

Fig. 1. XRD patterns of the whitening agents used in the study. Peaks shown are for corundum (C), anatase (A), baddeleyite (B), zircon $(\mathrm{Z})$, quartz $(\mathrm{Q})$.

Particle size distribution of the TABLE III whitening agents.

\begin{tabular}{c|c|c}
\hline \hline Whitening agent & $<d(0.5)[\mu \mathrm{m}]$ & $<d(0.9)[\mu \mathrm{m}]$ \\
\hline A & 2.496 & 9.153 \\
B & 2.931 & 19.983 \\
C & 4.207 & 23.050 \\
D & 1.939 & 5.871 \\
E & 1.241 & 2.740
\end{tabular}

It is seen that all of the critical temperatures of the studied frits were lower than the standard one. With the exception of Frit (D), the studied frits' sintering and softening temperatures were $\approx 100-140^{\circ} \mathrm{C}$ lower than the standard one. The reduction in the sintering and softening temperatures could be explained with the melting temperature of the components. The melting temperatures of alumina and zircon are $2072{ }^{\circ} \mathrm{C}$ and $2550^{\circ} \mathrm{C}$, respectively. Therefore, the alumina based whitening agents could be dissolved during frit melting process. Thermal behaviour of frit $\mathrm{D}$ was similar to standard one. This behavior could be related to chemical composition of agent $\mathrm{D}$, which has a high zircon and silica content, similar to zircon opacifier.

Hot stage microscope analyses of frits $\left({ }^{\circ} \mathrm{C}\right)$.

TABLE IV

\begin{tabular}{c|c|c|c|c|c}
\hline \hline Frit compos. & $\mathrm{T}_{\text {Sinter. }}$ & $\mathrm{T}_{\text {Soften }}$. & $\mathrm{T}_{\text {Sph. }}$ & $\mathrm{T}_{\text {Half Sph. }}$ & $\mathrm{T}_{\text {Melt. }}$ \\
\hline STD Frit & 946 & 1042 & 1116 & 1154 & 1186 \\
Frit (A) & 820 & 920 & 1096 & 1138 & 1188 \\
Frit (B) & 814 & 926 & 1060 & 1102 & 1156 \\
Frit (C) & 828 & 926 & 1060 & 1104 & 1140 \\
Frit (D) & 932 & 1024 & 1076 & 1132 & 1152 \\
Frit (E) & 836 & 920 & 1002 & 1108 & 1148
\end{tabular}

The XRD patterns of the glaze samples are shown in Fig. 2. Beside standard glaze, zircon phase was detected only in glaze (D). This result can be explained with the higher level of zircon content in whitening agent D (zircon content $\approx 40 \mathrm{wt} . \%$ ). Although, whitening agents of $\mathrm{A}$ and $\mathrm{C}$ have more than $>90 \mathrm{wt} . \%$ alumina; any of alumina based phase was not found in glaze (A) and glaze $(\mathrm{C})$. This result suggest that alumina based whitening agents 
did not react with glassy phase to form any other crystalline phases during firing. Unlike these glazes, kyanite phase $\left(\mathrm{Al}_{2} \mathrm{SiO}_{5}\right)$ was observed in glaze (B).

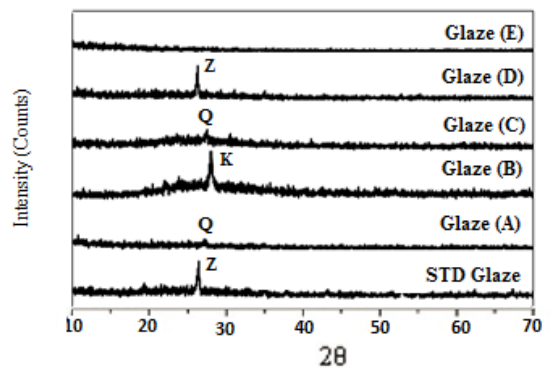

Fig. 2. XRD patterns of the ceramic glazes. Peaks shown are for zircon $(\mathrm{Z})$, quartz $(\mathrm{Q})$ and Kyanite $(\mathrm{K})$.

Opacifiers provide opacity to the glaze by scattering and reflecting the light that is incident on the coating. The factors that control the opacity in glazes include the difference in refractive index between the glass and opacifier, the number, size, shape and distribution of the opacifier particles, the incident light wavelength and the glaze thickness [1]. The $L^{*}$ indice of the glaze could be a good value for comparing the opacity of the glazes. When the difference of $L^{*}$ indices of unglazed wall tile and the glazed tile increase, it could be said that opacity of the glaze has increased. When the opacities are compared, it is seen that none of the studied glazes has reached the value of the standard glaze (Table V). Glaze (A), (B) and (C) showed $L^{*}$ indices between $77-78$, similar to the unglazed wall tile. This transparency could be explained with the XRD patterns. Glaze $\mathrm{C}$ and $\mathrm{E}$ show only glassy phase in its XRD pattern, glaze B shows only kyanite phase. However glaze (D) and (E) show higher $L^{*}$ indices $(81-83)$ than the unglazed wall tile; their whiteness indices were not adequate for catching the standard value $(88.8)$. This small increments in $L^{*}$ values could be a result of zircon devitrification in these glazes. Although, XRD pattern of glaze (D) confirmed this result, there wasn't found any phase in glaze (E). Therefore microstructure analysis should be done to ensure that lower amount of zircon crystallization occurred or not in glaze (E).

The matt and glossy appearance of the glazes is explained with the amount of specular reflectance from the glaze surface. When a surface is less than smooth, some of the light reflected specularly from the surface is reflected at angles other than the incident light, because the surface was not flat at the point of interaction. Hence, the apparent specular reflectance is reduced, and with it, the gloss [5]. For that reason, lower glossiness of glaze (A), (B) and (C) could be explained with the boiling surfaces which caused higher roughness. Glaze (D) and (E) show higher glossiness than the standard glaze. This result can be explained by the lower sintering and softening temperatures of the glazes, which has caused lower viscosity and so lower roughness.
Colour indices and the gloss param-

TABLE V eters of the glazes.

\begin{tabular}{c|c|c|c|c}
\hline \hline Glazes & $L^{*}$ & $a^{*}$ & $b^{*}$ & Glossiness $\left[60^{\circ}\right]$ \\
\hline Wall Tile & 78.75 & 5.54 & 16.42 & - \\
STD Glaze & 88.91 & 1.42 & 2.29 & 78.5 \\
Glaze (A) & 78.81 & 5.1 & 4.38 & 11.7 \\
Glaze (B) & 78.08 & 5.39 & 15.31 & 29 \\
Glaze (C) & 77.98 & 5.5 & 15.6 & 59.5 \\
Glaze (D) & 82.81 & 3.46 & 6.74 & 90.1 \\
Glaze (E) & 81.73 & 3.94 & 8.75 & 83.3
\end{tabular}

\section{Conclusion}

In this study, it has been shown that the replacement of industrial whitening agents, at the expense of zircon, causes a decrease in the sintering and softening temperatures. All of the glazes prepared with alumina based whitening agents, showed transparent and boiling appearance. Industrial whitening agents with zircon, alumina and silica content showed higher opacity but still their values were not adequate to reach the standard glaze opacity. These glazes also show higher glossiness than standard glaze. This result can be attributed to the lower sintering and softening temperatures of the glazes, which caused lower viscosity and so lower roughness. Results suggest that alumina with zircon and silica based whitening agents could be good candidates for zircon in opaque frit compositions. For this purpose new frit formulations have to be studied to determine the correct ratio of zircon and whitening agent in the frit recipes.

\section{Acknowledgments}

The authors would like to thank Prof. Dr. Alpagut Kara from Anadolu University and the Ceramic Research Centre of Turkey for the research support.

\section{References}

[1] Meinssen K, Ceramic Glaze Materials: The Top Ten List in: 98th Annual Meeting and the Ceramic Manufacturing Council's Workshop and Exposition: Materials and Equipment/Whitewares: Ceramic Engineering and Science Proceedings 18, 308 (1997).

[2] R. Casasola, J. Ma Rincon, M. Romero, Journal of Materials Science 47, 553 (2012).

[3] C.W. Parmalee, Ceramic Glazes, Cahners Books, Boston, 1973.

[4] Sainz, I.G, Tile Brick International 6, 21 (1990).

[5] R.A. Eppler, D.R. Eppler, Glazes and Glass Coatings, American Ceramic Society, 2000. 